\title{
INTERVENSI MODEL PENDIDIKAN DAN KOMUNITAS TENTANG INFLUENZA MENURUT MAHASISWA KEDOKTERAN DAN KEPERAWATAN
}

\author{
Andyana Sabtisan, Priska Yunianti, Bryani Titi Santi, Dwi Jani Juliawati, Elisabeth Rukmini \\ Medical Education Unit, Fakultas Kedokteran Universitas Katolik Indonesia Atmajaya
}

\begin{abstract}
Background: Medical awareness and clinical management of seasonal influenza remains limited in Indonesia. As future health workers, nursing students' and medical students' knowledge, attitude, and practice regarding influenza and influenza vaccine are important to make patients have better understanding about influenza. We explored their ideas about community intervention and education models regarding influenza and influenza vaccine. The aims of this study were to obtain nursing students' ideas about community intervention models and medical students' idea about education models regarding influenza and influenza vaccine.
\end{abstract}

Method: A qualitative study using in-depth interview was conducted towards 10 nursing students and 10 medical students to explore their opinions and ideas about community intervention and education models regarding influenza and influenza vaccine.

Results: Nursing students' ideas for community intervention models were varied. Most of them mentioned poster, leaflet, workshop, counselling, and free influenza vaccination. There were also some interesting ideas, such as influenza handbook, influenza educational song, influenza car campaign, and popular science article about influenza. As for medical students, the education model they proposed was mostly seminar, workshop, pre-clinic training, and visual media such as poster and video.

Conclusion: The study highlights the needs to educate future health workers about influenza and influenza vaccine to improve knowledge, practice and attitudes. Innovative and up-to-dateintervention models regarding influenza and influenza vaccine are needed to improve the health workers' quality.

Keywords: influenza, community intervention model, education model

\section{ABSTRAK}

Latar belakang: Kesadaran medis dan penanganan klinis influenza masih terbatas di Indonesia. Sebagai calon tenaga kesehatan, pengetahuan, sikap, dan perilaku mahasiswa keperawatan dan mahasiswa kedokteran terkait influenza dan vaksinasi influenza merupakan hal yang penting agar pasien memiliki pemahaman yang lebih baik tentang influenza. Kami mengeksplorasi ide mereka terkait model intervensi komunitas dan model pendidikan terkait influenza dan vaksinasi influenza. Tujuan dari studi ini adalah untuk memperoleh ide mahasiswa keperawatan mengenai model intervensi komunitas dan ide mahasiswa kedokteran mengenai model pendidikan terkait influenza dan vaksinasi influenza.

Metode: Penelitian ini dilakukan secara kualitatif menggunakan wawancara mendalam terhadap 10 mahasiswa keperawatan dan 10 mahasiswa kedokteran untuk mengeksplorasi pendapat dan ide mereka mengenai intervensi komunitas dan model pendidikan terkait influenza dan vaksin influenza.

Hasil: Ide mahasiswa keperawatan terkait model intervensi komunitas bervariasi. Kebanyakan dari mereka menyebutkan poster, leaflet, workshop, penyuluhan, dan vaksin influenza gratis. Terdapat juga beberapa ide menarik seperti buku saku influenza, lagu pendidikan terkait influenza, kampanye mobil influenza, dan

korespondensi: nanarinne94@gmail.com 
artikel ilmiah populer mengenai influenza. Sementara pada mahasiswa kedokteran, model pendidikan yang kebanyakan mereka usulkan adalah seminar, workshop, pelatihan pre-klinik, dan media visual seperti poster dan video.

Kesimpulan: Studi ini menandai pentingnya kebutuhan untuk mendidik calon tenaga kesehatan mengenai influenza dan vaksin influenza untuk meningkatkan pengetahuan, sikap, dan perilaku. Model intervensi yang inovatif dan efektif terkait influenza dan vaksin influenza dibutuhkan untuk meningkatkan kualitas tenaga kesehatan.

Kata kunci: influenza, model intervensi komunitas, model pendidikan

\section{PENDAHULUAN}

Terjadinya epidemi influenza setiap tahun di dunia mengakibatkan mortalitas dan morbiditas global meningkat. The Centers for Disease Control and Prevention(CDC) memperkirakan bahwa setidaknya terdapat 200.000 excess hospitalizations dan sebanyak 36.000 orang Amerika meninggal setiap tahunnya karena influenza dan komplikasinya. Dari semua penyakit yang dapat dicegah dengan vaksin, infeksi virus influenza merupakan penyakit yang paling banyak memakan korban. ${ }^{1}$ Epidemi influenza musiman terjadi setiap tahun selama musim gugur dan musim dingin di daerah beriklim sedang. Di negara tropis, virus influenza beredar sepanjang tahun dan terjadi peningkatan selama musim hujan.

Penggunaan vaksinasi influenza tergantung pada pandangan penatalaksana dan petugas kesehatan serta persepsi masyarakat terhadap influenza dan vaksinasi influenza. Di Indonesia, pandangan petugas kesehatan terhadap vaksinasi influenza masih buruk. Dua alasan utama menolak pemberian vaksinasi influenza adalah miskonsepsi yaitu kurangnya pengetahuan mengenai infeksi virus influenza dan kurangnya akses vaksinasi influenza. ${ }^{2,3}$

Berbagai model referensi dikembangkan untuk meningkatkan pengetahunan dan sikap. ${ }^{1,47}$ Namun demikian pengetahuan dan sikap saja tidak cukup untuk membuat seseorang tergerak untuk memperoleh vaksinasi influenza. Motivasi juga berperan dalam kesediaan seseorang untuk memperoleh vaksinasi. Intervensi berupa model pendidikan tradisional dinilai tidak efisien untuk mengubah sikap dan perilaku seseorang karena kurangnya aspek motivasional, sehingga dibutuhkan suatu model intervensi pendidikan yang inovatif dan dapat meningkatkan motivasi seseorang untuk mengubah sikap dan perilakunya. ${ }^{8}$ Kampanye di komunitas juga banyak dipakai untuk mengubah praktik masyarakat terhadap pencegahan influenza., ${ }^{9} 10$

Sementara itu dalam tahap komunitas, sebuah penelitian di Afghanistan menemukan bahwa masyarakat yang mendapat intervensi dari kampanye IEC (Influenza-like-illness surveillance and information, education, and communication) memiliki pengetahuan dans ikap yang lebih baik mengenai influenza dibandingkan dengan masyarakat yang tidak walaupun secara keseluruhan tingkat pengetahuan kedua kelompok masih di bawah standar yang seharusnya. Kampanye IEC merupakan suatu bentuk edukasi masyarakat menggunakan pamflet dan pesan-pesan yang disiarkan oleh radio dan televisi, namun hasilnya tidak terlalu signifikan untuk semua golongan masyarakat. Untuk meningkatkan keberhasilan bentuk intervensi ini, perlu dibuat suatu pesan dengan struktur bahasa yang didesain khusus bagi masyarakat dengan status pendidikan dan sosial ekonomi yang rendah. Edukasi intensif terutama diberikan terlebih dahulu kepada para pemimpin komunitas dengan menggunakan bahasa yang sederhana.

Penelitian tentang intervensi model pendidikan untuk mempersiapkan tenaga kesehatan yang handal dan melakukan edukasi terhadap komunitas menjadi penting dan menarik untuk dilakukan. Tujuan penelitian ini adalah mengeksplorasi intervensi model pendidikan dan intervensi bagi komunitas terkait 
dengan masalah influenza dan vaksinasi influenza dari sudut pandang mahasiswa kedokteran dan keperawatan. Pilihan pada mahasiswa keperawatan untuk mengemukakan ide tentang intervensi bagi komunitas berdasarkan pada hasil studi awal yang menunjukkan mahasiswa keperawatan lebih peduli pada perkembangan kesehatan di taraf komunitas dibandingkan mahasiswa kedokteran. ${ }^{11,12}$ Sementara itu, pilihan mahasiswa kedokteran sebagai pengusung ide intervensi model pendidikan dianggap penting sebab di tengah masyarakat kelak, dokter akan menjadi pemimpin atau manajer.

\section{METODE}

Penelitian ini merupakan penelitian deskriptif eksploratif yang menggunakan desain penelitian crosssectionaldan mixed-method research. Mixed-method research merupakan suatu penelitian yang menggabungkan pendekatan kuantitatif dan kualitatif sekaligus untuk menjawab suatu masalah penelitian. Dalam penelitian ini, pendekatan kuantitatif dilakukan untuk memperoleh gambaran pengetahuan, sikap, dan perilaku (PSP) yang dikumpulkan dalam satu waktu menggunakan kuesioner PSP untuk influenza dan vaksinasi influenza. Kuesioner disusun berdasarkan studi literatur PSP serupa dengan modifikasi secukupnya yang ditujukan pada mahasiswa bidang profesi kesehatan. Kuesioner kemudian diuji coba terlebih dahulu pada kelompok mahasiswa Fakultas Kedokteran berjumlah 20-25 orang.

Sementara itu, pendekatan kualitatif dilakukan dengan metode in-depth interview (wawancara mendalam) untuk mengeksplorasi pendapat mahasiswa keperawatan mengenai intervensi yang perlu dilakukan terhadap komunitas untuk edukasi mengenai influenza dan vaksinasi influenza. Sebelum melakukan analisa data, hasil rekaman proses wawancara mendalam ditranskripsi terlebih dahulu ke dalam bentuk teks. Data kualitatif yang didapatkan kemudian dikelompokkan menurut tema yang telah ditentukan oleh peneliti. Tema ditentukan melalui proses inter-rater, yaitu suatu proses diskusi antara peneliti dengan pembimbing penelitian. Setelah kesepakatan dalam diskusi tercapai, peneliti selanjutnya akan melakukan coding terhadap semua data hasil transkripsi verbatim.

\section{HASIL DAN PEMBAHASAN}

\section{Intervensi model pendidikan}

Sebanyak $81 \%$ responden menganggap bahwa pengetahuan mereka tentang influenza dan vaksinasi influenza masih kurang. ${ }^{11,12}$ Model intervensi pendidikan yang dianjurkan mahasiswa adalah kelas, teladan, media visual, seminar dan motivasi. Selain itu, partisipan berpendapat agar mahasiswa kedokteran dan bidang profesi kesehatan dimotivasi untuk membaca jurnal, textbook, web yang mempunyai informasi terkait influenza dan vaksinasi influenza, seperti WHO dan CDC, maupun bahan-bahan yang didapat dari perkuliahan. Pendapat partisipan dalam studi ini mirip dengan penelitian-penelitian terdahulu. ${ }^{13}$

"Hmm mengerti ya, ya berarti kayak tadi kan ... dimasukkan ke dalam perkuliahan, mungkin juga disertakan sih buku-buku sumber bacaan, dan mungkin di perpus juga bahkan sudah disiapkan bukunya apa saja yang memang ada di ehm..emang mencakup mengenai materi influenza ini. Dan juga selain itu juga bisa juga bisa kalau nggak mau pakai buku, misalnya disediakan handout-nya, kira-kira influenza isinya apa aja, seperti itu, ringkasan singkat ataupun in-depth-nya juga boleh. Selain dari... tadi dengan cara, dengan cara-cara tersebut mungkin juga bisa juga mahasiswa disuruh juga untuk membuka internet, misalnya daripada website CDC seperti itu kan pasti ada keterangan mengenai influenza dan vaksinnya. Nah itu juga kita bisa mendapatkan data yang cukup menarik dan cukup interesting bagi mahasiswa dari situ." (Mahasiswa FK)

Pada masa kini, model pendidikan yang lebih diminati mahasiswa berusia 20 tahunan adalah tipe edukasi yang menggunakan jejaring sosial. Partisipan juga menganggap bahwa interaksi sosial berbasis internet dapat digunakan dalam model pendidikan.

"Hmm kalau dari media sosial yang sekarang apa ya yang lagi diminati banyak orang gitu ya mungkin bias bikin video promosi kayak eh yah sepertita di misalnya vaksin influenza jadi kalau poster kan mungkin orang merasa bosen gitu kan, kalau video kan lebih 3D lebih ada animasi gitu kan lebih menarik jadi orang-orang bisa lebih tahu gitu lewat video ato ga eh 
misalnya poster di kampus mungkin ga dibaca juga cumin asal lewat mungkin di instagram mungkin siapa yang ngepost gitu lebih oh ia apa nih menarik banget posternya, dibaca.. seperti itu." (Mahasiswa FK).

Role modeling dianggap sebagai bagian penting dari pendidikan kedokteran, tetapi role modeling dirasa masih kurang oleh partisipan. Tenaga kesehatan yang tidak memberikan contoh yang baik dianggap tidak memotivasi mahasiswa untuk berbuat baik juga. Pendidikan yang diberikan oleh tenaga kesehatan pada ruang praktek juga dianggap dapat membantu meningkatkan pengetahuan, sikap dan perilaku responden terhadap influenza. Seorang dokter, selain meresepkan obat-obatan, dapat juga memberikan edukasi mengenai influenza, apa yang harus dilakukan ketika sedang sakit dan juga cara prevensi agar tidak terkena influenza di kemudian hari.

"Eh biasanya kan orang kalau misal kita ingin melakukan sesuatu yang baik kita harus melakukan sesuatu dulu sebagai teladannya. Nah kalau misalnya dalam hal kesehatan tentu tenaga kesehatan yang penting, memegang peran penting supaya masyarakat eh bisa meniru apa yang baik mengetahui apa yang baik dari eh misalnya vaksin influenza seperti itu, makanya menurut saya eh tenaga kesehatan itu juga perlu dilakukan vaksin influenza itu eh terus dengan mendapat vaksin influenza terus hidup sehat kemudian menjaga kebersihan di masyarakat yang kalau liat eh mereka bisa hidup sehat gitu bisa terbebas dari influenza mungkin mereka bisa lebih percaya gitu daripada kita hanya ngomong oh vaksin influenza tuh baik loh atau blah blah blah blah gitu. Tapi kalau misalnya dilakukan sendiri oleh tenaga kesehatannya mungkin masyarakat lebih percaya lagi terutama dalam hal mahasiswa kedokteran. Mahasiswa kedokteran juga harus eh apa ya semacam eh jadi model." (Mahasiswa FK)

\section{Intervensi model komunitas}

Untuk intervensi model komunitas yang didapatkan dari wawancara mendalam mahasiswa keperawatan didapatkan beberapa tema, antara lain penyuluhan, poster, iklan, seminar, pendekatan personal, vaksinasi gratis, organisasi kesehatan dan usulan pemerintah.
"Kalau penyuluhan.. ya kurang lebih tiga puluh menit lah kecuali kalau lebih dari tiga puluh menit biasanya orang sudah tidak konsentrasi, tiga puluh menit tetapi langsung ke intinya kepada kan kalau influenza kan ya pengertiannya kita tahu kan virus kaya begitu kan lebih tidak usah diperdalamin bagaimana cara penularannya." (Mahasiswa STIKES Keperawatan)

"Ya...kalau misalnya penyuluhan gitu biasanya apa dulu itu influenza...seberapa tahu mereka tentang influenza, kemudian ee... bagaimana sih cara kita mengatasi influenza itu, dampaknya apa ketika kita tidak memberikan tindakan... penanganannya tidak cepat terhadap orang-orang influenza...terus ee...kemudian bagaimana pencegahannya...itu yang paling utama pencegahannya supaya influenza itu tidak terjadi, mungkin dengan vaksinasi atau dengan cara lain." (Mahasiswa STIKES Keperawatan)

Penyuluhan dianggap sebagai salah satu metode intervensi komunitas yang efektif untuk menyampaikan beberapa informasi terkait influenza dan vaksinasinya. Informasi yang perlu disampaikan dalam penyuluhan tersebut antara lain pengertian dari influenza, dampaknya, serta pencegahan dan penanganan dari influenza. Kebanyakan responden mengusulkan 30 menit sebagai durasi waktu ideal untuk penyuluhan.

Pemilihan media untuk penyampaian informasi dalam penyuluhan juga cukup penting. Pada umumnya media yang dapat digunakan menurut responden adalah powerpoint dan lembar balik. Namun jika menggunakan powerpoint, harus tersedia sarana listrik, laptop dan layar LCD. Oleh karena itu, jika lokasi penyuluhan tidak memungkinkan untuk sarana tersebut maka lembar balik dapat menjadi pilihan alternatif.

"Karena kalau powerpoint, mereka kurang apa ya... mungkin bukan tidak efektif, tapi lebih baik lembar balik karena sarananya pun di masyarakat berbeda juga. Ga semua dari mereka akan punya powerpoint.... untuk powerpoint, lcd, dan segala macam. Jadi mungkin lebih efektif dengan lembar balik dan mereka pun akan lebih aware karena lembar balik biasanya cuma tulisan apa itu influenza, apa sih itu 
vaksinasinya kurang lebih. Banyak yang bisa mereka ungkapkan daripada kita dengan powerpoint." (Mahasiswa STIKES Keperawatan)

Selain powerpoint dan lembar balik, kegiatan bermain peran (roleplay) juga dapat dijadikan media penyampaian informasi dalam penyuluhan. Melalui kegiatan roleplay, peserta diajak untuk mempraktikkan langsung hal-hal yang disampaikan dalam penyuluhan, misalnya dalam hal pencegahan influenza dimana peserta dilatih untuk mencuci tangan dengan benar, etiket batuk dan bersin dan sebagainya.

Selain penyuluhan, dapat juga diselenggarakan suatu acara edukasi dalam skala besar yaitu seminar. Seminar untuk edukasi influenza dan vaksinasi influenza selain diadakan untuk masyarakat umum, dapat juga diselenggarakan khusus untuk kalangan pelajar SMA dan mahasiswa bidang profesi kesehatan yang diintegrasikan sebagai bagian rangkaian acara lomba ilmiah bertema influenza, seperti lomba poster dan karya tulis ilmiah tingkat nasional.

"Saya pikir mungkin itu bisa diawali dengan lomba karya tulis ilmiah atau poster soalnya pelajar sekarang tertarik sekali dengan lomba-lomba seperti itu ya, tentunya ada hadiahnya juga. Nah terus, setelah diawali dengan lomba kemudian bisa juga diundang ke seminar influenza itu tapi bedanya dengan seminar untuk masyarakat umum, di seminar ini dibanyakin permainanannya atau ada demonstrasi cara penggunaan vaksinnya begitu." (Mahasiswa STIKES Keperawatan)

Durasi waktu yang dianggap ideal bagi seminar adalah 2 jam. Penyelenggaraan acara seminar ini juga dapat disertai dengan pemberian suvenir berupa pulpen atau pin yang dapat didesain dengan unsur influenza dengan tujuan agar ketika benda tersebut digunakan, pesan edukasi akan menjadi lebih mudah diingat. Selain itu, agar dapat mengundang antusiasme masyarakat untuk menghadiri acara seminar tersebut maka sebaiknya seminar tersebut menampilkan bintang tamu atau pembicara yang dikenal oleh masyarakat luas.
Poster sebagai media visual juga cukup banyak disebutkan sebagai metode intervensi komunitas untuk edukasi influenza dan vaksinasi influenza. Media poster dianggap tepat sebagai metode intervensi karena dapat ditempel di berbagai tempat sehingga dapat dilihat oleh berbagai kalangan masyarakat.

Komponen informasi yang perlu ditampilkan dalam poster antara lain adalah tanda dan gejala influenza, komplikasi, cara pencegahan dan cara kerja vaksin influenza. Kebanyakan responden menyukai poster yang memiliki desain full colour dengan komponen visual yang lebih dominan atau sedikit komponen teks. Poster ini juga dapat ditempel sebagai majalah dinding di sekolah atau kampus sebagai metode intervensi untuk pelajar dan mahasiswa.

Dalam melakukan intervensi komunitas untuk edukasi influenza dan vaksinasi influenza terhadap kalangan tertentu, beberapa responden berpendapat bahwa sebaiknya metode yang digunakan adalah pendekatan personal. Menurut mereka, metode ini tepat untuk digunakan dalam melakukan intervensi terhadap para pekerja kesehatan karena kesibukan pekerja kesehatan di rumah sakit atau klinik terkadang membuat mereka tidak sempat atau malas untuk menghadiri acara seminar karena merasa sudah cukup tahu dan berpengalaman menangani pasien di rumah sakit.

Salah satu bentuk pendekatan personal yang diusulkan oleh responden adalah sharing. Dalam kegiatan sharing, yang perlu dibagikan adalah infoinfo dan fakta ilmiah terbaru mengenai influenza dan vaksinasinya sehingga timbul rasa kepercayaan dari pendengar terhadap pemberi info dan proses transfer ilmu pengetahuan dapat terjadi tanpa memperhatikan perbedaan status antara mahasiswa dengan petugas kesehatan.

Banyak responden yang ingin mencoba vaksinasi dan mengusulkan agar biayanya gratis supaya orang-orang yang masih belum mengetahui vaksinasi influenza tertarik untuk melakukannya.

"terus sarana lainnya adalah vaksin gratis. Itu akan lebih efektif sih...karena siapa sih yang enggak mau gratis. Itu akan orang lebih efektif...lebih enak juga... terus bagaimana dinas kesehatannya yang lebih 
di....di......apa ya.....digunakan lah ya....istilahnya lebih digalakkan untuk influenza ini supaya dari dinas kesehatan, biasanya kan mereka lebih yang.... lebih punya sarananya untuk ke masyarakat... ke sekolah-sekolah....atau lebih ke.....mereka lebih punya sarananya begitu." (Mahasiswa STIKES Keperawatan)

Vaksinasi influenza gratis selain dianggap efektif untuk menarik perhatian masyarakat yang belum mengenal vaksin influenza juga tepat sebagai model intervensi untuk masyarakat dengan status ekonomi menengah ke bawah sebab vaksinasi gratis dapat diintegrasikan sebagai bagian dari pelayanan terhadap pemegang kartu miskin dan Kartu Jakarta Sehat (KJS).

Agar model intervensi komunitas untuk edukasi dan vaksinasi influenza dapat menjangkau seluruh lapisan masyarakat di berbagai tempat, diperlukan suatu komunitas atau organisasi kesehatan yang bergerak dalam upaya edukasi influenza dan vaksinasi influenza. Selain melakukan edukasi, organisasi ini juga melakukan upaya pencarian dana agar masyarakat dari golongan status ekonomi menengah ke bawah juga dapat memperoleh edukasi dan vaksinasi influenza secara gratis.

"Atau mungkin juga dari tenaga kesehatan mungkin yang peduli bisa menyisihkan- seperti kayak istilah iuran atau dari organisasi yang sudah dibentuk itu, ada iurannya tiap bulan atau apa itu kan dana bisa dipakai untuk orang-orang yang miskin kayak begitu." (Mahasiswa STIKES Keperawatan)

Pencarian dana dapat dilakukan dengan 2 cara, yaitu pencarian dana internal dan eksternal. Dana internal antara lain dapat diperoleh dari iuran keanggotaan, tarif pemeriksaan glukosa darah, dan mengamen. Sementara dana eksternal dapat diperoleh melalui pengajuan proposal untuk mencari sponsor yang bersedia mengadakan pembiayaan terkait edukasi dan vaksinasi influenza, antara lain dokter spesialis, rumah sakit, dan perusahaan farmasi yang memproduksi vaksinasi influenza.

Peran pemerintah dianggap penting dalam upaya intervensi komunitas untuk edukasi influenza dan vaksinasi influenza. Oleh karena itu, responden memiliki banyak usulan kepada pemerintah yang dapat dimasukkan ke dalam proposal untuk diajukan secara formal. Proposal yang berisikan usulan untuk pemerintah dapat diajukan oleh perorangan atau organisasi kesehatan.

"Bisa juga kita buat proposal kan ke pemerintah yang dijelaskan secara terperinci begini-gini tetapi memang kalau menurut saya kalau minta dari pemerintah kita juga harus jelas apakah akan influenza ini semakin meningkat atau tidak kan di masyarakat yang menengah ke bawah sehingga dana yang dikeluarkan oleh pemerintah-sehingga dana juga dikeluarkan oleh pemerintah seperti itu. Terus, ee bisa juga kita buat kayak ada dana sosial begitu kita minta dari apa begitu orang-orangnya yang mau memberikan gitu lah." (Mahasiswa STIKES Keperawatan)

Hal-hal yang dapat dimasukkan ke dalam proposal antara lain mengenai situasi penyakit influenza di Indonesia, mencakup jumlah penderita, tingkat kematian, dan perilaku penanganan influenza saat ini. Orang yang mempresentasikan proposal tersebut di depan pemerintah harus menguasai semua isi materi proposal dengan baik untuk dapat meyakinkan pemerintah agar mengeluarkan kebijakan yang dapat mendukung pelaksanaan intervensi komunitas untuk edukasi influenza dan vaksinasi influenza.

Dalam usulan terhadap pemerintah tersebut juga terdapat pengadaan iklan edukasi influenza sebagai peran pemerintah dalam intervensi komunitas untuk edukasi dan vaksinasi influenza. Iklan tersebut perlu dibuat dengan menarik agar dapat menjangkau masyarakat luas dan dapat ditayangkan melalui media elektronik dan media sosial. Salah satu desain iklan yang menarik antara lain dalam bentuk animasi mengenai influenza dan disertai dengan lagu yang menarik agar orang yang menyaksikan iklan itu juga dapat mempelajari tentang influenza dan vaksinasi influenza melalui media tersebut.

"Peran pemerintah yang pertama untuk yang jingle, terus apa ya iklan itu tugasnya pemerintah yang utama. Kalau untuk itu kan yang tidak real ya secara media, kalau untuk realnya mungkin dia yang bikin acara untuk kalangan menengah ke bawah 
dan menengah ke atas gitu." (Mahasiswa STIKES Keperawatan).

\section{KESIMPULAN}

Dari hasil penelitian kualitatif mengenai intervensi model pendidikan terkait influenza dan vaksinasi influenza, didapatkan hasil: (1) Mahasiswa berpendapat bahwa untuk meningkatkan pengetahuan dapat dilakukan intervensi pendidikan melalui edukasi oleh tenaga kesehatan, media visual, interaksi online, seminar dan membaca jurnal atau literatur, (2) untuk meningkatkan sikap dan perilaku dapat melalui teladan tenaga kesehatan profesional dan pengembangan motivasi. Sedangkan metode intervensi komunitas untuk meningkatkan pengetahuan, sikap, dan perilaku terkait influenza dan vaksinasi influenza yang paling banyak mahasiswa usulkan antara lain adalah penyuluhan, seminar, poster, leaflet, dan vaksinasi gratis.

\section{SARAN}

Metode intervensi yang digunakan untuk meningkatkan pengetahuan, sikap, dan perilaku mahasiswa kedokteran dan keperawatan terkait influenza dan vaksinasi influenza sebaiknya berupa kuliah yang terintegrasi dengan studi kasus agar dapat meningkatkan motivasi mahasiswa untuk belajar dan menerapkan ilmu tersebut dalam kehidupan nyata. Sementara untuk masyarakat umum, metode intervensi yang sebaiknya digunakan adalah penyuluhan, poster, leaflet, dan vaksinasi gratis.

\section{DAFTAR PUSTAKA}

1. Beckett CG, Kosasih H, Ma'roef C, Listiyaningsih E, Elyazar IRF, Wuryadi S, et al. Influenza surveillance in Indonesia: 1999-2003. Clin Infect Dis. 2004; 39:443-9.

2. Tricco AC, Chit A, Hallett D, Soobiah C, Meier G, Chen $\mathrm{M}$, et al. Effect of influenza vaccines against mismatched strains: a systematic review protocol. Syst Rev. 2012; 1: 35.

3. Sedyaningsih ER, Isfandari S, Soendoro T, Supari SF. Towards mutual trust, transparency and equity in virus sharing mechanism: the avian influenza case of Indonesia. Ann Acad Med Singapore. 2008; 37: 482-8.

4. Poland GA. Valuing influenza vaccine: medical, economic, and social benefits. Clin Infect Dis. 2009; 48: 299-301.

5. BBC Indonesia. Indonesia tak perlu khawatirkan flu burung [Internet]. BBC Indonesia 4 Jan 2012.

6. Chickering AW, Gamson ZF. Seven principles for good practice in undergraduate education. AAHE Bull [Internet]. 1987 [cited 2014 Nov 17]; Available from: http://eric.ed.gov/?id=ED282491.

7. Afonso N, Kavanagh M, Swanberg S. Improvement in attitudes toward influenza vaccination in medical students following an integrated curricular intervention. Vaccine. 2014 ;32(4):502-6.

8. Askarian M, Danaei M, Vakili V. Knowledge, attitudes, and practices regarding pandemic H1N1 influenza among medical and dental residents and fellowships in Shiraz, Iran. Int J Prev Med. 2013;4(4):396-403.

9. Van D, McLaws M-L, Crimmins J, MacIntyre CR, Seale H. University life and pandemic influenza: attitudes and intended behaviour of staff and students towards pandemic (H1N1) 2009. BMC Public Health. 2010;10(1):130.

10. Seale H, Mak JP, Razee H, MacIntyre CR. Examining the knowledge, attitudes and practices of domestic and international university students towards seasonal and pandemic influenza. BMC Public Health. 2012;12(1):307.

11. Sabtisan A. Pengetahuan, sikap, dan perilaku serta model intervensi komunitas terkait influenza dan vaksinasi influenza menurut mahasiswa keperawatan. 2014.

12. Yunianti P. Pengetahuan, sikap, dan perilaku serta model intervensi pendidikan terkait influenza dan vaksinasi influenza menurut mahasiswa kedokteran. 2014.

13. Blake T. Teaching musculoskeletal examination skills to UK medical students: a comparative survey of rheumatology and orthopaedic education practice. BMC Med Educ. 2014; 1462. 